\title{
Creating learning and action space in South Africa's post-apartheid land redistribution program
}

\author{
Thembela Kepe and Ruth Hall
}

\begin{abstract}
This paper uses the case of South Africa's latest land redistribution strategy known as the Proactive Land Acquisition Strategy, to explore whether, and how, research can have direct and positive impacts on beneficiaries of land reform. The study is situated within the practice of action research: to explore how it can generate knowledge that can be shared back and forth between stakeholders, as well as how it may ignite changes that the participants desire. The findings are that Proactive Land Acquisition Strategy is not meeting the overall goals land reform. But action research has allowed the beneficiaries to emerge from the process with new knowledge about their rights, as well as what options they have to move forward in their fight for secure land rights and decent livelihoods. We introduce a concept of a 'learning and action space' to explain our practice of action research. The paper concludes that action research is a desirable approach for land reform, but while it succeeded in educating beneficiaries, it is only one ingredient in ongoing struggles to challenge power relations among citizens and between citizens and the state.
\end{abstract}

\section{Introduction}

Over the last decade or so, one of the biggest stories concerning land and justice globally has been the escalation of land deals initiated by individuals, corporations and governments of wealthy countries in poor or developing countries. Commonly known as 'land grabbing', these land deals are often criticized for their dubious effects on the livelihoods and land rights of the poorest and most marginalized people in the affected countries (Borras \& Franco, 2012; Li, 2014). However, in many countries of the global south the most salient land issue has to do with the challenges of dealing with the legacies of colonialism, which resulted in large-scale, often violent, land dispossessions of the local people by colonial powers. Our focus in this article is on the latter: the difficulties of undoing the 'land grabs' of the past and bringing about reconciliation and justice in these societies.

In the case of South Africa, land, including all its multiple meanings that encompass its importance as a natural resource, sense of identity, power and territory (Fisher, 2016; Kepe, Hall, \& Cousins, 2008; Li, 2014), was central to colonial conquest and apartheid, as well as to the struggle against these forces. Precisely because of these 
multiple meanings of land, in dealing with colonial and apartheid land injustices, the state has to go far beyond a simple restoration of property. It needs to work at restoring people's dignity, trust and the relationship with land and with each other (Andrews, 2006; Atuahene, 2007; Hendricks, Ntsebeza, \& Helliker, 2013; Walker, Bohlin, Hall, \& Kepe, 2010). Indeed, at least on paper, these were some of the principles guiding South Africa's post-apartheid land reform policy, the White Paper on South African Land Policy (Department of Land Affairs, 1997), which emphasized justice, reconciliation, economic growth and improved livelihoods as the intended outcomes of land reform.

As one the post-apartheid government's top five priorities since 1994, the land reform program was envisioned as one of several policies that would spark economic growth and promote equity through a combined agrarian and industrial strategy (Cousins, 2013). The three mechanisms used to fulfill these goals have been: land restitution, to restore land rights to victims of racially motivated dis- possession that happened after 1913; the reform of land tenure, to secure and protect contemporary land rights that were left vulnerable by apartheid; and land redistribution, to promote more equitable access to land and address the needs of the landless, labor tenants, farm workers and emerging farmers (Department of Land Affairs, 1997). This paper focuses on the latter. Despite the widely acknowledged centrality of land in South Africa's post-apartheid project of redress and better life for all, land reform has been judged to have failed to meet its goals that are embodied in the Constitution and the original land policy (Cousins, 2013; Gibson, 2009; Walker, Bohlin, Hall, \& Kepe, 2010). In particular, land redistribution has arguably been the most visible failure in the land reform mandate. Less than 10\% of the land has been redistributed since 1994 (Umhlaba Wethu, 2009; Walker, 2013), despite the promise by the state to redistribute $30 \%$ of commercial agricultural land within the first five years of the postapartheid dispensation (Department of Land Affairs, 1997). It is therefore not surprising that the vast majority of Black people in South Africa believe that historical land injustice has not been adequately addressed by the post-apartheid government (Gibson, 2009).

Leading up to, and continuing well after, the official end of apartheid, marginalized populations mounted robust campaigns for land justice. During the 1980 s and 1990s, many non-government organizations and other groupings provided platforms from which ordinary people could organize and launch their struggles against land injustice (see Claassens, 1991; Mngxitama, 2006; Naidoo, 1997). These organized land struggles were intense in both urban and rural areas, where there were large concentrations of people with shared grievances (Cobbett \& Cohen, 1988). Following the official end of apartheid, however, the organization of land struggles in urban and rural areas faced numerous challenges. Arguably the most important challenges facing organized land struggles by the marginalized people were, first, the weakening of the NGOs focusing on land rights, due to leadership vacuum left by people who went on to join the mainstream political institutions of the post-apartheid government (local, provincial 
and national) (Habib \& Taylor, 1999). Second, the post-apartheid government, pressured by the need to appease outsiders and neoliberal agendas, came down harshly on land activism such as that of the Landless People's Movement that threatened the state's portrayal of the country as peaceful and safe to invest in. Mngxitama (2006, p. 39) has skillfully analyzed the 'taming of land resistance' by the post-apartheid government, showing how powerful land NGOs such as the National Land Committee buckled under government pressure. A more visible and violent expression of the postapartheid state's disdain for land activism was the formation of paramilitary units that used physical force to prevent and reverse 'land occupations' by landless people. Examples of these units include the Red Ants in Johannesburg and the Anti- land Invasion Unit in Cape Town (Hendricks \& Pithouse, 2013).

In addition to these challenges to land activism in South Africa, research has shown that, partly due to geographical isolation, the landless poor who live on farms belonging to others (mostly white farmers) continue to be in worse conditions than their counterparts in urban areas and rural villages (Naidoo, 1997; Ntsebeza, 2013; Webb, 2016; Wegerif, Russell, \& Grundling, 2005). Farm workers tend to face the challenge of hostile farm owners who oppose labor union activities, as well as the limited attention paid by organized movements to the challenges facing farm workers. Those who are 'beneficiaries' of land reform are also isolated and face ongoing difficulties after settling on land acquired for redistribution. As Kepe (2012) argues, many of these people depend on state support for livelihoods, legal and business advice. In turn, there is an element of paternalistic treatment by the state, making it difficult for land reform beneficiaries living on 'commercial' farms to oppose official advice (e.g. land use proposals).

In this paper, we use the case study of the latest land redistribution strategy known as the Proactive Land Acquisition Strategy (PLAS), to explore whether, and how, research can have direct and positive impacts on how the beneficiaries achieve the intended goals of land redistribution (Department of Land Affairs, 2006). We situate this study within the practice of action research: to explore how it can generate knowledge about the plight of land redistribution beneficiaries, as well as how it may ignite changes that the people desire.

In the next section, we present a brief discussion in which we frame our approach to understanding the challenges, as well as the needs, of land redistribution 'beneficiaries' within the tradition of action research. We also provide a ration- ale for its use in this study. This is followed by a discussion of land redistribution that includes a review of PLAS. We then present our preliminary findings and explain how we combined research and advocacy activities in our action research. The last section of the paper presents a discussion and conclusion. 


\section{Learning and action through action research}

We need to declare that our motivation for carrying out the study is rooted in our belief that injustices affecting other people should be a concern for all of us (Gibson, 2009). We both have a history of activism in the areas of land justice, poverty and human rights, and have worked on land rights issues in non-government organizations and as academic researchers. This background, as well as the current failures of South Africa's land reform, convinced us of a need to forge closer ties between local people's participation, knowledge production and action for change. Thus, our vision for engagement with land redistribution beneficiaries is rooted in the four defining characteristics of action research, as summarized by Denscombe (2010). First, we envisaged a research process that is of practical nature, in that its focus is real-life challenges facing people. Second, in addressing the practical challenges, change is seen as the necessary outcome of research. Third, the research is seen as involving an iterative process, whereby research findings trigger advocacy for desired changes, which may then be implemented and evaluated as a preface to further action. Lastly, although not the least, research participants are seen as the central and necessary elements of the research process. Ideally, this is what all social science research should strive for, but we acknowledge that traditional research is often caught up in particular codes of conduct, including intellectual clarity and objectivity, to mention a few (Altrichter, Kemmis, McTaggart, \& Zuber-Skerritt, 2002). Therefore, our approach in this study is opposed to the notion of an objective, value-free approach to knowledge creation (Brydon-Miller et al., 2003). Rather, we believe that in situations where the participants or local people suffer injustices under oppressive or authoritarian environments (Cahill, 2007; Drake, 2013), researchers should feel no guilt in favoring 'explicitly political' and socially-engaged research (Brydon-Miller, Greenwood, \& Maguire, 2003, p. 13).

Much like other research approaches that focus on participation, such as participatory rural appraisal (PRA) that was popularized by people such as Chambers (1994a, $1994 b, 1994 c)$, action research is known to face challenges. Some of these challenges relate to the dangers of using the approach as simply a buzz word (Cornwall, 2007), often ignoring heterogeneity and power differentials of people at the local level (Kapoor, 2002). The other major challenge is ensuring that knowledge creation has legitimacy and that research data are verifiable (Beylefeld, 2005; Beylefeld, Bitzer, \& Hay, 2007). Linked to this last point is that action researchers should always guard against the temptation of using the need for 'action' to ignore ethical conduct of research (Denscombe, 2010). In our own study, we kept these challenges in mind, ensuring that all the participants in the research gave informed consent and that some (of the 'beneficiaries') willingly agreed to partner with us in pushing for action relating to land reform. Another caveat that we note, which our research experience made abundantly clear, is that action research is demanding, thus not allowing large-scale activities. Also, it is not easy to claim that it was done 'by the book', as some local dynamics did not make it possible to include all the traditional steps of participatory research (e.g. engaging in a highly inclusive long process of problem definition by 
local participants). As Altrichter, Kemmis, McTaggart, and Zuber-Skerritt (2002) argue, action research should not be seen as a perfect and complete process, as it is continuing to develop as a practice, relying on the very process of research to refine it.

In our approach, we make reference to the 'space' that action research creates for both co-learning and action for change. We acknowledge the often-contested notions of 'space' as conceived from different disciplinary perspectives. So we limit our reference to 'space' to what we believe action research contributes to social reality of certain individuals. Drawing from field theory, Friedman et al. (2016) argue that social spaces are constructed through interaction, and that these inter- actions are in turn shaped by the spaces that they generate, to allow people to see new ways of knowing and acting. They further argue that action then takes place through a complex web of social life or fields. Wiley et al. (2010) see social space as being constituted by assemblages, among other things, that link people via net- works in order to do something, including creating solidarity and forming com- munity, among other things. This is why we see the 'learning and action space' we aimed to achieve as facilitating the exchange of information that can lead to action, by acknowledging social space as necessarily diverse and dynamic (Garmany, 2008). In our case, however, we believe learning and action not only happens at the community level, but also at the realm of researchers and other outsiders working with local people (e.g. state officials). We therefore define 'learning and action space' as an assemblage of opportunities over a period of time, in which both the researcher and the researched learn through the process of research and jointly and separately pursue action as a result of this learning with the intent to change the circumstances of the researched in pursuit of social justice. In this paper, we share our own critical reflections on our action research practice and its strengths and limitations in creating such a space for us and for those we interacted with.

\section{The evolution of state-controlled land redistribution}

Land redistribution in post-apartheid South Africa has gone through several phases, with limited success. The first phase (1994-1999) involved the state offering Settlement/Land Acquisition Grants (SLAG) of R15, Ooo $^{1}$ to households that had a maximum monthly income of R1500. These grants were meant to provide modest land to the poor for settlement and multiple livelihood purposes (Lahiff, 2007). However, the small grants on offer made it almost impossible for individual house- holds to have viable livelihoods, especially those based on farming. The result was ineffective large group farming projects, as households were encouraged by government to pool their resources together, to be able to purchase farmland (Hall, 2009). Additionally, these large group projects were handicapped by the state, as they did not receive posttransfer support for infrastructure, technical support, agricultural training or market access (Cousins, 2013). The second incarnation of land redistribution, the Land Redistribution for Agricultural Development programme (LRAD) (2000-2011), was explicitly intended to enable the emergence of a class of black commercial farmers, but was later moderated to address a variety of land needs and constituencies, ranging from 
'the landless', farm workers, women, emerging entrepreneurs and established commercial farmers (Hall, 2009). Despite offering larger grants ranging from R20,000 to $\mathrm{R} 100, \mathrm{Ooo}^{2}$ to those with their own capital or loans to invest, a limit on the number of participants per project meant that the poorest members of society could not participate, as they could not accumulate enough grants and own capital to afford farms at market price (Hall, 2009). Additionally, problems encountered in the first phase were replicated (e.g. under- utilization of farmland and poor support by the state) and the second phase also introduced a new problem of over-indebtedness as aspiring farmers took out substantial loans to buy farms. Although LRAD resulted in an increase in the number of land redistribution projects, it fell far short of the pace for meeting the target of redistributing 30\% of the agricultural land by 2014 (Lahiff, 2008).

The latest incarnation of land redistribution, the PLAS, piloted from 2006, and rolled out nationally from 2011, involves the state purchasing farms and making them available on a leasehold basis to beneficiaries (Department of Land Affairs, 2006). This program was envisaged as a way to address many of the failings of the previous two programs. However, despite very limited reviews of the program, the first few years of it has produced more questions than answers. With the state remaining the owner of the land used by beneficiaries, a question arises of whether or not this form of redistribution fulfills the mandates of land reform that include redressing past land injustices, promoting equity including gender equity, and reducing poverty. Additionally, it remained to be seen if anything was changing in terms of state support to beneficiaries. In addition to our own observations and understanding of the state's commitment and readiness for implementing land reform over the last 20 years, it is these questions that prompted us to conduct action research in Sarah Baartman District in the Eastern Cape Province.

\section{Land redistribution in Sarah Baartman District, Eastern Cape}

Prompted by public pronouncements by politicians and officials of the DRDLR about the progress of, and the large amounts of money invested in, land redistribution, as well as the well-publicized criticism of its slow pace and inappropriateness, we decided to conduct a small-scale study to interrogate its outcomes. We chose to focus on Sarah Baartman District, in the Eastern Cape. The Eastern Cape has consistently been one of poorest provinces in South Africa (Kepe \& Tessaro, 2014; Westaway, 2012), particularly due to the presence of the two Black reserves (homelands or Bantustans) of Ciskei and Transkei, the poorest rural areas throughout the apartheid years. The latest population statistics from the country's 2011 census show that this province has about 6.5 million people, and has an expanded unemployment rate of $51 \%$ (ECSECC, 2012). The provincial government has consistently pushed for both commercial and subsistence agriculture to be given strong support as key elements for improving food security (Kepe \& Tessaro, 2014). 
Other motivations for conducting action research in Sarah Baartman District had to do with our personal connections to the area. First, both of us were born and grew up in this district. We both have a fairly good grasp of historical land injustices and poverty in the area, as well as deep concern about their continuation following the official end of apartheid over two decades ago. We have a degree of social networks and local knowledge to draw on. Second, a chance meeting with the chairperson of the Portfolio Committee on Rural Development and Land Reform in the Eastern Cape Provincial Legislature, who also originally comes from the district, provided some legitimacy to our choice of the area. Upon hearing about our interest in doing such research, the chairperson indicated that his provincial parliamentary colleagues would be happy to learn more about how land redistribution is unfolding in one of the province's districts. He went a step further and provided us with an official letter endorsing our study, which we were able to use when approaching managers and project officers dealing with land reform and agriculture, as well as potential research participants.

Our choice of research participants was based on a combination of purposive and quota sampling and convenience strategies (Denscombe, 2010; Scheyvens, 2014). Sampling was purposive in that we targeted people who were beneficiaries of the PLAS program. We used quota sampling to ensure that all possible key variations in the characteristics of the projects were included. Lastly, convenience sampling made sense because the early stages of our research were not funded. In addition to the rationale explained above for our choice of district, we chose cases that we could visit within reasonable time and without huge financial costs involved. However, to choose the sample we had to get the database of all land redistribution beneficiaries under the PLAS program in the district. These records are kept at the district and provincial offices in Port Elizabeth and East London, respectively. For familiar reasons, officials in these offices were either evasive or reluctant to release the database. It took several weeks of calling, emailing, faxing and personal connections to finally get the lists. From the lists were then able to take a quota sample, mainly based on land use (crop or livestock), size of the farm and the number of beneficiaries in each project, as listed in the database. Having drawn our sample, we were able to obtain from the DRDLR a list of phone numbers for the beneficiaries in these projects that we used for initial contact. Upon these phone calls, we were able to work with 11 projects (each representing one farm). Ten of these were in Sarah Baartman District, while one was in Amathole District, which was included because it was spatially on the border between the two districts and, through a personal connection, it was the very first farm visited that we were able to use as a pilot. We later decided that we should not discard it once we began our study in Sarah Baartman.

To arrange for farm visits, we used the contact phone numbers that were listed in the database we received from the officials. On each land redistribution project, in addition to the number of people per project, one contact person and details were listed. In all cases these were mobile phone numbers. In our initial contact with these people we 
had no idea what their role in the project was. As it turns out, out of the 11 cases we contacted, six were the actual land reform beneficiaries, four were strategic partners/mentors and one was a former resident on the farm who left it before the land was given to the beneficiaries. All the beneficiaries were immediately eager to talk to us after we explained our research goal and what we intended to do with the information. The strategic partners, all of whom were white men, on the other hand, did not sound thrilled by our proposed visit but still provided us an audience.

In our initial visits to the farms we again introduced our research to the contact people, and sought informed consent to conduct our research. In the case of the strategic partners and mentors, upon our initial meeting and getting background details about the farm and its beneficiaries, we insisted on engaging with the actual beneficiaries of the project. Following hesitation from the strategic partners and mentors, we were able to engage with the beneficiaries. However, more often than not the strategic partners or mentors remained present, and at times tried to answer our questions on behalf of the beneficiaries. We therefore obtained the beneficiaries' contact details, so that we could make arrangements to meet with them separately so that they would be free to talk to us, in the absence of the strategic partners/mentors, and also follow up and remain in contact by phone. This worked out very well. In cases where there were no strategic partners/mentors, the research process went on without many challenges.

\section{Fieldwork}

Our engagement with the participant land reform beneficiaries in Sarah Baartman has lasted about three years thus far. In our initial visits, following our introduction and informed consent from the participants, our approach focused on getting the beneficiaries to provide, in as much detail as possible, their history on and aspirations for the farm. In particular, we wanted details about how they got to be beneficiaries on the land; when they became beneficiaries; what size the farm was; their current livelihoods; assets on the farm, including livestock; their aspirations in terms of land use and livelihoods; the kind of rights they hold; challenges they faced; and their interactions with government officials in relevant departments, or other agencies and NGOs. In subsequent visits we updated the information received, as well as sought to understand what the beneficiaries saw as a way forward to resolve their challenges. In addition to the semi-structured interviews and other interactions, we did direct observations of assets on the farm, as well as any other activities and interactions that were relevant to their situation as beneficiaries. In particular, we recorded our observations about the quality of their livelihood sources, including how being 'beneficiaries' might have changed their welfare, for the better or for the worse.

In line with our goal of contributing to the improvement of the beneficiaries' welfare, we created a space for the beneficiaries to ask questions and receive education on matters relating to the challenges they faced. In short, whenever we sensed that the beneficiaries had poor understanding of policies or practices relating to land reform or 
development programs, we presented them with information where we could. Thus we drew from our knowledge and experience working on land reform issues to explain specific relevant policies; corrected misinformation they might have had; and provided advice on where and to whom they can turn to, if they needed assistance (e.g. legal help, NGOs and state agencies). In one case we secured the support of a human rights litigation NGO whose staff visited the farm and advised the beneficiaries. Additionally, we read and translated documents the beneficiaries had, that were clearly not wellunderstood before.

As part of our information sharing with the participants, we negotiated and undertook to keep them informed about how we used information gained from them. Our three main undertakings were that, first, we would immediately share our findings with relevant state actors, including district and provincial offices, as well as the national department dealing with land reform and rural development. Second, we undertook to inform relevant NGOs about the beneficiaries' challenges and encourage them to intervene where possible. Third, we undertook to make follow-up visits and keep in close communication by phone where necessary and possible.

\section{Summary offindings}

Our findings reveal, among other things, five key challenges facing PLAS and the beneficiaries. First, there was no real production taking place in most of the farms. But there were exceptions: three farms that were managed and operated by agribusiness companies as the 'strategic partners' and, to a smaller extent, two others that were operated by middle class family members with external sources of income. The rest of the farms were in a poor state, including being environmentally degraded, and not having had any notable production for several years. This raises questions about the state's goal of targeting high-value land for redistribution in order to boost agricultural production and contribute to economic growth as part of the rationale for the PLAS program.

Second, most the PLAS land reform beneficiaries had either expired leases, expired 'care-takership' agreements, or no documented land rights at all. This left beneficiaries feeling vulnerable in terms of their land rights, with one mentioning that 'Sihleli ngempundu enye' (an isiXhosa saying meaning 'We are sitting on one bum cheek' - that is, we know we can be asked to move at any time and there is nothing we can do about it). The only exceptions were three farms where the government had concluded leases with the strategic partners, rather than with the beneficiaries. Due to their land tenure insecurity, beneficiaries were unable to receive production support from other government departments, as well as unable to secure loans from financial institutions. One former farm worker put it as follows: 'We have tried on many occasions to get help from the Department of Agriculture, but they tell us that they can't help us because we do not have a lease and that we are part of PLAS, which is managed by a different department (Department of Rural Development and Land Reform)'. Another beneficiary stated how they are forced to defy some state regulations 
because they are pushed into a corner, mentioning that 'We are in fact doing things that we were not allowed to do under the lease. But we don't have a lease, so we do them anyway. One of those things is that we are leasing out grazing land to a neighbor'. Third, one of the very few possibilities for the beneficiaries to receive production support from the state was through the Recapitalisation and Development Programme ('Recap'). Launched in 2010, Recap aimed to provide struggling land reform projects with technical and financial support. However, in order to qualify for Recap support, beneficiaries have to have a business plan, and either a mentor or a strategic partner. In all our cases these potential mentors or strategic partners were white male farmers. Some of these 'farmers' had either already left or abandoned the farming business for having failed to make viable the very enter- prises that they were mentoring or partnering with. In all the cases where strategic partnerships or mentorships existed, the beneficiaries claimed that they felt like farm workers, rather than partners or independent farmers. This raised serious questions about justice, reconciliation, equity and dignity that are among the goals of land reform in South Africa.

Fourth, former farm workers who remained on the farms as beneficiaries, after the state purchased them from their former employers, were the most vulnerable. Having lost employment, with limited or no farming taking place, as well as the restrictive land tenure agreements - documented or expired or not - former farm workers had to rely on relatives in towns and cities, or eked out a living through food gardens and selling off their remaining livestock. In some cases, the former farm workers lacked basic necessities such as water and sanitation, but could not receive infrastructural support from other government agencies or non-government organizations due to the land being owned by the DRDLR. Hunting is generally forbidden, as is sub-letting parts of the farm - yet we found both practices quite widespread, given the absence of viable livelihood opportunities from farming.

Additionally, some former farm workers resorted to counter-productive alternatives to survive. For example, a former farm worker said 'When we worked as farm workers for the whites we had acceptable livelihoods. But after the government took over the farm, we lost our jobs and initially relied on selling scrap metal from implements on the farm to be able to eat'. The last important finding is that there was generally poor communication between beneficiaries and the relevant state department responsible for land reform and rural development. The majority of beneficiaries stated that they do not receive any visits or support from the relevant project officers. Even when the beneficiaries were the ones initiating contact, they claimed that officials did not always respond to phone calls to address problems. In short, beneficiaries felt abandoned by the relevant state departments, as well as clueless about many issues relating to their status as land reform beneficiaries. 


\section{Dissemination and iterative processes of research and action}

In keeping with the goals of action research, and fulfilling our commitment to take the study beyond just learning about the beneficiaries' challenges, we engaged in at least four strategies to disseminate findings that we see as part of a cyclical or iterative process of feedback and seeking positive change for the beneficiaries. These included working with project officers and managers in the DRDLR at district and provincial level; reaching out to politicians at local, provincial and national level; lobbying relevant people and institutions for attention to the cases; and sharing the findings through presentations in many public forums, including in the provincial legislature and national parliament.

We thus, firstly, shared the findings during the first year of the research with the district and provincial officials of the DRDLR in Port Elizabeth (district office) and East London (provincial office), respectively. For the provincial presentation, we requested for a local NGO to also join the meeting and invited beneficiaries from some projects to attend the meeting. The focus in presenting the findings was to highlight the lack of secure rights to the land for the beneficiaries, as well as the impediments people faced in making use of their land. Our purpose was to show a pattern - and a pattern that contradicted the core tenets of policy. The second goal of the visits to these offices was to discuss with the officials the possible reasons underlying this pattern, the constraints and considerations that shape their practice as implementers, and to identify unclear or problematic provisions in the PLAS policy, and how these may be mitigated on the ground. The third goal of the presentations was to engage in conversations that could yield action plans by the district or provincial offices, to address some of the challenges emerging from the study. At least at the provincial office, an action plan to address bottlenecks in the cases was developed, with implementation set at only a few weeks from the date of the meeting. In these initial meetings it was clear that the officials were aware of many of the challenges presented, but were not aware of the effects on beneficiaries and were uncertain how to address them. Officials were also defensive at times. With the attention drawn to the case studies, we shared the outcomes of these meetings with the beneficiaries through further visits and telephone conversations.

Secondly, we sought and received invitation to share the findings with various political offices. During the first year we presented at the Eastern Cape provincial parliament. The presentation was well received by the provincial political parties, some of whom were shocked to hear about the challenges on the farms. For this provincial parliament meeting, we also invited representatives of an NGO working with land reform beneficiaries and farm workers, and secured opportunity for the NGO to make an input as part of the presentation. During the second year of the action research we sought and received an invitation to present to the national Minister of Rural Development and Land Reform in Cape Town. The Minister could not make the meeting, instead asking the Deputy Minister to receive us. The meeting was also attended by several highranking officials of the department, some video conferencing from national office in 
Pretoria. Prior to the meeting we prepared a short policy brief that we sent to all those attending the meeting. In preparing for the meeting, we made contact with beneficiaries at our case study farms and asked them to articulate what they wished us to share with the Minister's office, which they did, and this was incorporated in presenting the cases and pro- posed ways forward in each case. The meeting demonstrated that the Deputy Minister and senior departmental staff were clearly unaware of many of the problems experienced by beneficiaries. The outcome of the Minister's meeting was a list of agreements between us as researchers and the DRDLR to work together in resolving some of the challenges. Specifically, we undertook to share all findings, as well as to widen our cases to include other provinces, using independent research funding. The Department undertook to allow us access to the national database so as to enable us to select further cases for action research. Following the meeting and several letters of reminder, however, we did not hear from the Department about what was agreed upon. As done before, we took the feedback, including new policy explanations we received, to the beneficiaries. We also interpreted the policy, checking our understanding with the ministry and national leadership, and wrote to the state officials responsible to explain, for instance, that a farm could not be subdivided after being allocated (even in the absence of a formal lease) as this constitutes an unlawful reduction in land rights; that the absence of a commercial farm plan and Recap is not reason to withhold a lease; and that long-term farm occupiers are entitled in terms of policy to retain the farm in perpetuity on the payment of a nominal rent of R1 per year - not a commercial rent set at a percentage of annual turnover.

Thirdly, as part of presentations to the district and provincial offices, as well as to politicians, our primary goal was to lobby for action that would improve the conditions of the beneficiaries. Ironically, it was our presentation to politicians at national level, rather than to the Ministry of Department, that yielded some action. In February 2015, we were invited to give evidence at hearings held by Parliament's Portfolio Committee on Rural Development and Land Reform, and presented our findings from this study, including details of three cases. This prompted the committee to request the DRDLR to investigate and to report back to Parliament on the resolution of the problems identified. As a result, the DRDLR organized a field trip together with us, bringing several officials from its national, provincial and district offices to visit a sample of cases from our research in May 2015. Following our brief introduction on each case, beneficiaries were invited to add, clarify and indicate how they would like the situation to be resolved. Officials then explored different ways they could address the challenges within policy and legal limits. The week after the joint field trip, the most senior of the visiting officials from Pretoria drafted a detailed work plan for the provincial and district offices to implement. The outcomes have been mixed, with a degree of progress in some of the cases, and no change in others. However, it was clear that the tour provided a hands-on opportunity for the officials from Pretoria - apparently not accustomed to these farm-level realities - to observe and appreciate 
the challenges faced by the beneficiaries, and that our research had succeeded in bringing these realities home to them.

Following the field trip, the national Minister visited some farms, and visited one farm twice, and provided much-needed housing to one group of beneficiaries. We have continued with the 'action' based on our research, writing numerous letters, making further follow-up visits to the farms and making phone calls to different relevant offices. The goal of these contacts was to lobby for action on the farms were working on, while raising awareness about the general challenges faced by PLAS. While not all our letters and phone calls were returned, we did get a request from the provincial director of DRDLR in the Eastern Cape to extend our study to include cases that they consider to be 'success stories'. We carried out their request, and gave them our findings, but we have not included that sample as part of this paper. Rather we have used the insights from those three cases to share with beneficiaries from our original cases, about what is going on at the farms deemed successful by the state, as examples of what they could argue for.

Lastly, we have used the findings to present insights in academic conferences in South Africa and overseas. Additionally, we have used the material for teaching at our respective universities. Our belief is that the more widely we share about the plight of the land reform beneficiaries, the more chances there are that the concerns will receive publicity and attention that can result in change. In addition to using the material for teaching, we have asked students to create a land use map for one of the farms, where the beneficiaries requested it, so that the various families living there could use it to negotiate their land uses.

\section{Discussion and conclusion}

Our research was prompted by our desire to investigate the outcomes of the PLAS, and to assess the extent to which it is realizing the original goals of land reform, such as redressing past racially-based land imbalances, securing land tenure, and contributing to better livelihoods for land reform beneficiaries (Department of Land Affairs, 1997). We adopted a version of action research to understand beneficiaries' challenges in PLAS projects, and in turn to create spaces for co-learning and action between relevant stakeholders and the beneficiaries. Farm dwellers and small-scale farmers are particularly marginalized and isolated in South Africa, making it difficult for them to organize and lobby government in the ways that people in urban areas do. Indeed, our main focus was to allow the beneficiaries to voice their views on how PLAS is going, and what challenges they faced as beneficiaries. In the cases we studied, PLAS has clearly failed to meet the goals of land reform, because both the policy and practice are chaotic and unclear at best, and at worst because of collusion between state officials, agribusinesses and wealthier farmers. We conclude that the state currently has limited capacity and commitment to implement land redistribution in the interests of the poor black rural population. 
In this concluding discussion, we wish to reflect on the process of using action research to understand the implementation of PLAS, and what prospects there are for this research approach in other similar situations. We believe there are a number of lessons that can be drawn from the action research that we engaged in. Firstly, researchers can gain deeper understanding and appreciation of land reform beneficiaries' challenges and hopes. Patience, and approaching the engagement with the participants with an open mind, yet political conviction, increased our sensitivity to the information emerging from the study. Secondly, given that we learned from, as well as shared knowledge with, the beneficiaries, both they and we emerged from the process with enhanced knowledge. We therefore see action research as being an effective method to promote education and empowerment. There is another, albeit indirect, way in which education worked positively for the beneficiaries. In our engagement with state officials and politicians we found our- selves explaining state policies and laws, and offering strategic advice to them, when it appeared that we had more knowledge than them. In turn, the new know- ledge by these stakeholders can (but does not automatically) improve their assistance to the beneficiaries. Thus, we see action researchers as educators (Brydon-Miller, Brydon-Miller, Greenwood, \& Maguire, 2003). Thirdly, the iterative process between researchers, research participants, state officials and politicians, appears to have provided a bridge through which conversations about the challenges faced by land reform beneficiaries can flow.

Fourthly, and related to the last point, our research has somewhat connected former farm workers who were 'beneficiaries' of PLAS with one another. We ensured that people in similar situations knew who else was in the same predicament, and we provided in each case a list of farm names and contact persons' names and phone numbers. In some cases, these beneficiaries from different farms were able to meet and share information. Fifthly, our dissemination of findings, and advocacy against the state's poor implementation of land reform, has prompted some action by state officials responsible for the projects. Sixthly, as a direct result of our action research, we prioritized our collaboration with land activist NGOs, some of which were able to push for change in more ways than we could. Finally, we conclude that action research can be seen as a deterrent to poor treatment of land reform beneficiaries by the state and by (white) strategic partners and (white) mentors. In many cases, the fact that we displayed an explicitly political research agenda, many of these stakeholders appear to have quickly understood that this was no ordinary research. They became aware that we would continue to follow up and monitor their actions, since achieving positive change was our primary objective.

However, as we were keenly aware throughout our advocacy research activities with land reform beneficiaries, researchers also risk alienating powerful actors, such as state officials, only to find that the losers in the process are the very people that the research sought to help. Thus, in all action research cases, we propose, researchers should be open about their political agendas, and should allow these to be influenced and directed by the people the research seeks to help. Scholarship with 
commitment, therefore, should include the researcher's commitment to not worsen the condition of the participants.

In short, we believe that action research has a potentially strong positive impact for land reform beneficiaries, but it is challenging and is ideal for research projects of limited scope. Action research in this context requires in-depth and long-term engagement. But we still believe that wider adoption of action research and its duplication throughout the country should be considered for land reform. We reiterate, after other scholars using this strategy, that our work in this action research should be seen as falling between activism and academic research (Lyons, 2014). Our characterization of the 'learning and action space' created through our practice of action research is one that places the politics of knowledge and responsibility for action at the center of the relationship between the researcher and the researched. In our practice of 'solidarity work' that transcends the traditional distinction between academic and activism, we draw inspiration from Routledge (1996) who termed this the 'third space', indicating academia as a site of resistance not disconnected from, but critically engaged with, society. As Bourdieu (2000) argues, scholarship with commitment should be a goal of social researchers. With political processes such as land reform, therefore, we believe researchers have no alternative but to be political, and to pursue the political aims of their research not only through learning but also through action.

\section{Declaration of Conflicting Interests}

The author(s) declared no potential conflicts of interest with respect to the research, author- ship, and/or publication of this article.

\section{Funding}

The author(s) disclosed receipt of the following financial support for the research, author- ship, and/or publication of this article: This research was supported by the Social Sciences and Humanities Research Council (SSHRC) of Canada [grant number 435-2014-0825].

\section{Notes}

1. Approximately $\$ 1000$ at the current exchange rate of ZAR 15 to the US dollar.

2. Approximately $\$ 1300-\$ 6700$ at the current exchange rate of ZAR 15 to the US dollar. 


\section{References}

Altrichter, H., Kemmis, S., McTaggart, R., \& Zuber-Skerritt, O. (2002). The concept of action research. The Learning Organization, 9(3), 25-31.

Andrews, M. (2006). Struggling for a life in dignity. In L Ntsebeza \& and R Hall. (eds). The Land Question in South Africa: The Challenge of Transformation and Reconciliation. Cape Town: HSRC Press.

Atuahene, B. (2007). From reparation to restoration: moving beyond restoring property rights to restoring political and economic visibility. SMU Law Review, $60(4), 1420-1470$.

Beylefeld, A. A. (2005). The challenge of creating knowledge through action research. South African Journal of Higher Education, 19, 1321-1333.

Beylefeld, A., Bitzer, E., \& Hay, H. (2007). Action research: A wonderfully uncomfortable mode of creating knowledge. Acta Academica, 39(1), 146-175.

Borras, S.M., \& Franco, J. C. (2012). Global land grabbing and trajectories of agrarian preliminary analysis. Journal of Agrarian Change, 12, 34-59.

Bourdieu, P. (2000). For a scholarship with commitment. Profession, 40-45.

Brydon-Miller, M., Greenwood, D., \& Maguire, P. (2003). Why action research? Action Research, 1(1), 9-28.

Cahill, C. (2007). The personal is political: Developing new subjectivities through participatory action research. Gender, Place \& Culture, 14(3), 267-292.

Chambers, R. (1994a). The origins and practice of participatory rural appraisal. World Development, 22(7), 953-969.

Chambers, R. (1994b). Participatory rural appraisal (PRA): Analysis of experience. World Development, 22(9), 1253-1268.

Chambers, R. (1994c). Participatory rural appraisal (PRA): Challenges, potential and para- digm. World Development, 22(10), 1437-1454.

Claassens, A. (1991). Rural land struggles in the Transvaal in the eighties. In S. Matlhape, \& A. Mu $\mathrm{po}$ (Eds.), Towards and new agrarian democratic order. Amsterdam: South Africa Economic Research and Training Project.

Cobbett, W., \& Cohen, R. (Eds.). (1988). Popular struggles in South Africa. Trenton, NJ: Africa World Press.

Cornwall, A. (2007). Buzzwords and fuzzwords: Deconstructing development discourse. Development in Practice, 17(4-5), 471-484.

Cousins B. (2013). Land reform and agriculture uncoupled: The political economy of rural reform in post-apartheid South Africa. In B Hebinck \& B Cousins (eds). In the Shadow of Policy: Everyday Practices in South African Land and Agrarian Reform. Johannesburg: Wits University Press.

Denscombe, M. (2010). Fourth Edition. The good research guide: For small-scale social research projects. Maidenhead, UK: Open University Press.

Department of Land Affairs. (1997). White paper on South African land policy. Pretoria: Department of Land Affairs.

Department of Land Affairs. (2006). The implementation framework for the Proactive Land Acquisition Strategy: 2006-2014. Pretoria: Department of Land Affairs. 
Drake, D. H. (2013). Researching prisoner experiences with prison officers: An action research-inspired approach. Action Research, 12(1), 94-109.

Eastern Cape Socio-economic Consultative Council (ECSECC). (2012). Census 2011 Key Results for the Eastern Cape. East London: ECSECC.

Fisher, D. (2016). Freeze-framing territory: Time and its significance in land governance. Space and Polity, 2O(2), 212-225.

Friedman, V. J., Sykes, I., Lapidot-Lefler, N., \& Haj, N. (2016). Social space as a generative image for dialogic organization development. Research in Organizational Change and Development, 24, 113-144.

Garmany, J. (2008). The spaces of social movements: O Movimento dos Trabalhadores Rurais Sem Terra from a Socio-spatial Perspective. Space and Polity, 12(3), 311-328.

Gibson, J. L. (2009). Overcoming historical injustices: Land reconciliation in South Africa. Cambridge: Cambridge University Press.

Habib, A., \& Taylor, R. (1999). South Africa: Anti-apartheid NGOs in transition. Voluntas, 1O(1), 73-82.

Hall, R. (2009). Another countryside? Policy options for land and agrarian reform in South Africa. Cape Town: Institute for Poverty, Land and Agrarian Studies, University of the Western Cape.

Hendricks, F., Ntsebeza, L., \& Helliker, K. (Eds.). (2013). The promise of land: Undoing a century of dispossession in South Africa. Auckland Park, South Africa: Jacana Media.

Hendricks, F., \& Pithouse, R. (2013). Urban land questions in contemporary South Africa: The case of Cape Town. In F. Hendricks, L. Ntsebeza, \& K. Helliker (Eds.), The promise of land: Undoing a century of dispossession in South Africa. Auckland Park, South Africa: Jacana Media.

Kapoor, I. (2002). The devil's in the theory: A critical assessment of Robert Chambers' work on participatory development. Third World Quarterly, 23(1), 101-117.

Kepe, T. (2012). Land and justice in South Africa: Exploring the ambiguous role of the state in the land claims process. African and Asian Studies, 11(4), 391-409.

Kepe, T., Hall, R., \& Cousins, B. (2008). 'Land'. In N. Sheppard, \& S. Robins (Eds.), The New South African key words. Athens: Ohio University Press and Johannesburg: Jacana Media. Kepe, T., \& Tessaro, D. (2014). Trading-off: Rural food security and land rights in South Africa. Land Use Policy, 36, 267-274.

Lahiff, E. (2007). 'Willing buyer, willing seller': South Africa's failed experiment in market- led agrarian reform. Third World Quarterly, 28(8), 1577-1597.

Lahiff, E. (2008). Land reform in South Africa: A status report 2008. Institute for Poverty, Land and Agrarian Studies, University of the Western Cape.

Li, T.M. (2014). What is land? Assembling a Resource for Global Investment. Transactions of the Institute of British Geographers, 39(4), 589-602.

Lyons, K. (2014). Critical engagement, activist/academic subjectivities and organic agrifood research in Uganda. Local Environment, 19(1), 103-117.

Mngxitama, A. (2006). The taming of land resistance: lessons from the national land com- mittee. Journal of Asian and African Studies, 41(1-2), 39-69. 
Naidoo, L. (1997). Paper rights: Organising farm workers. South African Labour Bulletin, 21(4), 27-30.

Ntsebeza, L. (2013). South Africa's Countryside: Prospects for change from below. In F. Hendricks, L. Ntsebeza, \& K. Helliker (Eds.), The promise of land: Undoing a century of dispossession in South Africa. Auckland Park, South Africa: Jacana Media.

Routledge, P. (1996). The third space as critical engagement. Antipode, 28(4), 399-419.

Scheyvens, R. (Ed.) (2014). Development Fieldwork: A Practical Guide. Thousand Oaks: SAGE Publications.

Umhlaba, W. (2011). A Bulletin Tracking Land Reform in South Africa. PLAAS, University of the Western Cape, Cape Town (Issue number 13).

Walker, C. (2013). The distribution of land in South Africa: An overview. PLAAS Land Reform Fact Check No. 1, 1-2.

Walker, C, Bohlin, A, Hall, R \& Kepe, T. (2010) (Eds.). Land, memory, reconstruction, and justice: Perspectives on land claims in South Africa. Athens: Ohio University Press; and Durban: University of KwaZulu-Natal Press.

Webb, C. (2016). Fire in the Vineyards: Farm Workers and Agrarian Change in Post- Apartheid South Africa. In T. Kepe, M. Levin and B. von Lieres (Eds.) Domains of Freedom: Justice, Citizenship and Social Change in South Africa. Cape Town: University of Cape Town Press.

Wegerif, M., Russell, B., \& Grundling, I. (2005). Still searching for security: The reality of farm dweller evictions in South Africa. Polokwane/Johannesburg, South Africa: Nkuzi Development Association/Social Surveys.

Westaway, A., (2012). Rural poverty in the eastern cape province: Legacy of apartheid or consequence of contemporary segregationism? Development Southern Africa 29(1), 115-125.

Wiley, S. B. C., Sutko, D. M., \& Becerra, T. M. (2010). Assembling social space. The Communication Review, 13, 340-372. 